\title{
The Potential of Renal Progenitor Cells in Kidney Diseases: Preclinical Findings
}

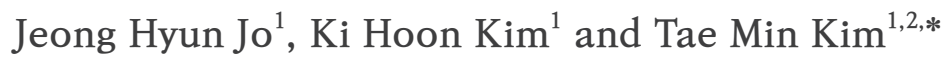 \\ ${ }^{1}$ Graduate School of International Agricultural Technology, Seoul National University, Pyeongchang 25354, Korea \\ ${ }^{2}$ Institute of Green-Bio Science and Technology, Seoul National University, Pyeongchang, 25354, Korea
}

Received June 20, 2019

Revised June 22, 2019

Accepted June 25, 2019

\author{
*Correspondence \\ Tae Min Kim \\ Graduate School of International Agricultural \\ Technology, Institute of Green-Bio Science \\ and Technology, Seoul National University, \\ Pyeongchang-daero 1447, Pyeongchang \\ 25354, Korea \\ Tel: +82-33-339-5896 \\ Fax: +82-33-339-5747 \\ E-mail: taemin21@snu.ac.kr \\ ORCID \\ https://orcid.org/0000-0003-0015-2701
}

\begin{abstract}
The kidney is a highly complex organ, and acute or chronic renal diseases can occur with various complications such as diabetes and hypertension. So far, no target specific treatment is available in acute or chronic renal failure, necessitating the development of alternative therapeutic strategy. Recent experimental findings suggest that the renal function and structure can be restored after being treated with various sources of stem/progenitor cells. In this review, we discuss up-to-date findings of the potential of renal progenitor/stem cells in alleviating renal injuries with a focus on preclinical studies. We also review cellular mechanisms underlying the therapeutic function of these cells.
\end{abstract}

Keywords: kidney, progenitors, regeneration

\section{INTRODUCTION}

Due to an increased incidence and associated morbidity, kidney disease is becoming a huge burden worldwide. Patients with diabetes or hypertension are at higher risk of acute kidney injury (AKI) (Togel and Westenfelder, 2012; Jha et al., 2013). Acute kidney injury (AKI) occurs by an acute loss of renal function due to ischemic, toxic or inflammatory insults. Current therapies for AKI mainly include supportive care and renal replacement therapy, which have been developed many years ago and these are not recognized as an efficient way due to the absence of specific therapeutic target (Jha et al., 2013). Recent studies demonstrated that various stem/progenitor cells have potential for enhancing tissue recovery after AKI, indicating that these cells may have therapeutic role in clinical uses (Hauser et al., 2010; Sedrakyan et al., 2012; Qi and Wu, 2013; Kuppe and Kramann, 2016). In this review, we highlighted several key findings on the use of renal progenitor cells for renal recovery in animal models. We also discussed the cellular mechanisms underlying their function.

\section{RENAL STEM/PROGENITOR CELLS}

Several reports are available on using various types of stem/progenitor cells. These include mesenchymal stem cells (MSCs) derived from bone marrow (Qi and Wu, 2013; Kuppe and Kramann, 2016), adipose tissue, amniotic fluid (Hauser et al., 2010; Sedrakyan et al., 2012). as well as MSC-like cells or renal progenitor cells residing in kidney (Wang et al., 2013). Renal progenitor cells have been identified in rodents and human, and their ability to localize within the kidney after injury or during development, or and their role in regeneration has been reported (Biancone and Camussi, 2014). In adult kidneys, these 
findings are mostly obtained by tracing a population of nephron cells that survive in tissue injury and differentiate into various subtypes of renal cells including tubular epithelial cells, podocytes, and collecting duct (Hansson et al., 2014; Rinkevich et al., 2014). In humans, CD133+ $\mathrm{CD} 24^{+}$renal epithelial cells have been identified to represent renal progenitor cells, occupying around $2-4 \%$ of total renal cell (Romagnani et al., 2013). Most of these progenitor cells are able to differentiate into several types of renal epithelial cell, like a podocyte, renal tubular epithelial cells, adipocytes, and endothelial cells (Sagrinati et al., 2006; Ronconi et al., 2009). However, most of these progenitor cells do not meet the general criteria for stem cells, i.e., their potential in self-renewal, clonogenicity and multi-lineage differentiation (Biancone and Camussi, 2014). In the following section, we provide the characteristics of renal progenitor cells and their therapeutic role in animal model of AKI.

\section{CHARACTERIZATION OF RENAL PROGENITOR CELLS}

Renal resident stem cells have been identified within various regions of kidneys including the interstitium, the tubules, and Bowman's capsule. The markers that are specific to those cells are different among the regions. Generally, CD $133^{+}$cells can be found in the overall area of kidney, e.g., Bowman's capsule, proximal tubule, Henle's loop, and distal convoluted tubule (Bussolati et al., 2005; Sagrinati et al., 2006; Ward et al., 2011). In human kidneys, resident glomerular MSCs have been characterized as CD133 negative and CD146 positive, and their ability to differentiate into endothelial, mesangial or glomerular cells has been reported (Bruno and Camussi, 2012). $\mathrm{CD} 133^{+} \mathrm{CD} 24^{+} \mathrm{CD} 106^{+}$cells are localized at the urinary pole of Bowman's capsule, and reported to have high proliferative potential, and differentiate into podocytes and tubular lineages. In addition, a distinct population of scattered $\mathrm{CD} 133^{+} \mathrm{CD} 24^{+} \mathrm{CD} 106^{-}$cells was localized in the proximal tubule as well as in the distal convoluted tubule, and reported to have a lower proliferative capacity, and displayed a committed phenotype toward the tubular lineage. Both showed higher resistance to injurious agent in comparison to all other differentiated cells of the kidney (Angelotti et al., 2012). It has also been reported that multipotent CD133/CD146 double positive cells are present in the adult decapsulated glomeruli, and that these cells express MSC markers as well as renal stem cell markers CD24 and Pax-2. The glomerular mesenchymal $\mathrm{CD} 133^{-} \mathrm{CD} 146^{+}$cells exhibited self-renewal capability, clonogenicity, and multipotency. In addition to osteogenic, adipogenic, and chondrogenic differentiation, these cells were able to differentiate to endothelial and epithelial cells expressing podocytes markers such as nephrin, podocin, and synaptopodin. Another study demonstrated that $\mathrm{CD} 133^{+} \mathrm{CD} 146^{+}$cells differed from those previously isolated from Bowman's capsule, as they expressed endothelial markers, such as CD31. Also, they were CD24 negative and lacked clonogenic potential, suggesting an endothelial commitment (Bruno et al., 2009). Functionally, these cells were able to enhance renal function in animal model of AKI, and were resistant to various injurious cues (Angelotti et al., 2012) (Fig. 1).

$\mathrm{c}^{-\mathrm{Kit}^{+}}$cells, another population having potential to dif-

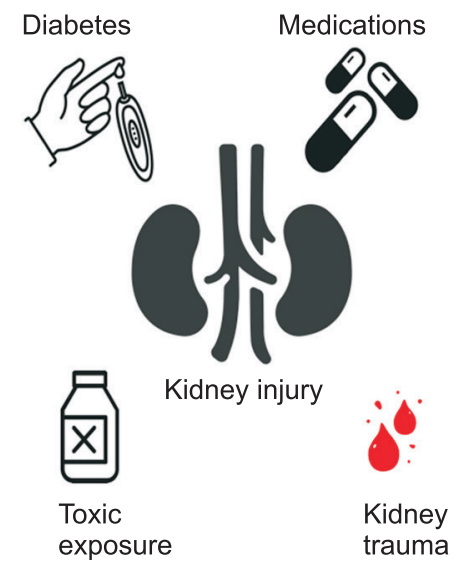

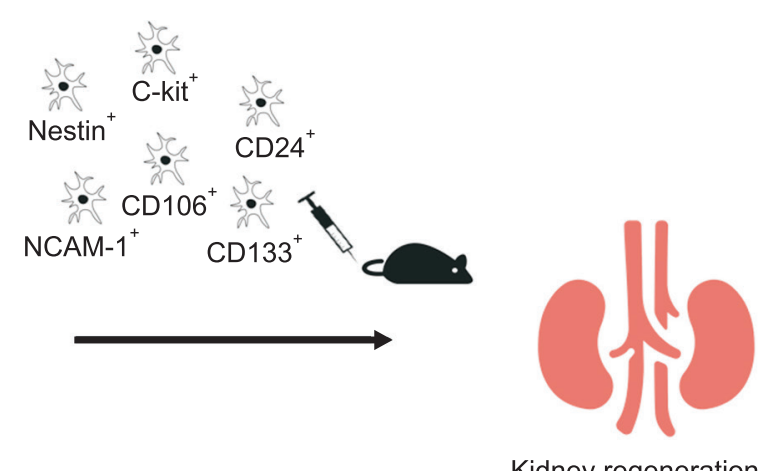

Kidney regeneration
Fig. 1. Schematic of kidney injury regeneration by renal progenitor cells. Renal injuries by toxin, drugs, excessive bleeding, or co-morbidities such as diabetes has been shown to be recovered by renal progenitors of different populations in preclinical study. 
ferentiate into renal lineages, are found in proximal tubular epithelial cells, Henle's loop, and focally or weakly in distal tubules, while negative in collecting tubules (Miliaras et al., 2004). Several mechanisms are involved in kidney regeneration by kidney-derived c-Kit ${ }^{+}$cells, including cell engraftment and differentiation into renal-like structures, such as tubules, vessels, and podocytes. Moreover, paracrine mechanisms could also account for kidney regeneration, either by stimulating proliferation of surviving cells or modulating autophagy and podocyte cytoskeleton rearrangement through mTOR-Raptor and -Rictor signaling, which ultimately leads to morphological and functional improvement of kidneys (Gomes et al., 2018). Other populations expressing markers including Nestin, CD24, or NCAM-1 were also found to have the potential to alleviate the renal function and structure in various animal models of AKI and renal fibrosis (for detailed explanations, please see Table 1).

\section{CONCLUSION}

Renal progenitor cells from fetal, infant, and adult kidneys have been shown to have potential to stimulate the recovery of AKI. However, current protocol for obtaining sufficient amount of renal precursor cells is technically difficult because most tissues are obtained from partial nephrectomy of renal cancer patients. Alternatively, generating renal lineage cells from induced pluripotent stem cells (iPSCs) would be another option considering the immune compatibility and the cell productivity. With better understanding of the biology of renal progenitor cells as well as bioengineering technique, renal progenitor cells will become an efficient tool for renal recovery from various injurious conditions.

Table 1. Therapeutic role of renal precursor cells in AKI

\begin{tabular}{|c|c|c|c|c|c|c|}
\hline Markers & $\begin{array}{c}\text { Cell } \\
\text { source }\end{array}$ & Route & Model & $\begin{array}{l}\text { Suggested } \\
\text { mechanisms }\end{array}$ & Major findings & References \\
\hline $\mathrm{CD}_{133^{+}}$ & Adult & IV & $\begin{array}{l}\text { Glycerol-induced } \\
\text { AKI in SCID mice }\end{array}$ & $\begin{array}{l}\text { Release of } \\
\text { Erythropoietin }\end{array}$ & $\begin{array}{l}\text { Inhibition of pro-inflammatory } \\
\text { cytokines and alleviation of } \\
\text { fibrosis at day } 60 \text { post-injury }\end{array}$ & (Aggarwal et al., 2016) \\
\hline $\begin{array}{l}\mathrm{CD} 133^{+}, \mathrm{CD}^{+} 4^{+} \\
\mathrm{CD} 106^{+}\end{array}$ & Adult & IV & $\begin{array}{l}\text { Glycerol-induced } \\
\text { AKI in SCID mice }\end{array}$ & $\begin{array}{l}\text { Engraftment within } \\
\text { the kidney }\end{array}$ & $\begin{array}{l}\mathrm{CD} 106^{+} \text {cells had regenerative } \\
\text { potential and were resistant } \\
\text { to apoptotic stimuli }\end{array}$ & (Angelotti et al., 2012) \\
\hline $\mathrm{CD}_{106^{-}}$ & & & & & $\begin{array}{l}\text { CD106 }^{-} \text {cells proliferated upon } \\
\text { tubular injury }\end{array}$ & \\
\hline $\begin{array}{l}\mathrm{CD}^{133^{+}} \text {and } \\
\mathrm{CD}^{-} 33^{-} \text {cells }\end{array}$ & Infant & IV & $\begin{array}{l}\text { Rat AKI (Cisplatin, } \\
7 \mathrm{mg} / 100 \mathrm{~g})\end{array}$ & $\begin{array}{l}\text { Paracrine or endocrine } \\
\text { factors from } \mathrm{CD}_{133^{+}} \\
\text {or CD133- cells }\end{array}$ & Improvement of renal function & (Santeramo et al., 2017) \\
\hline Nestin $^{+}$ & Adult & IV & $\begin{array}{l}\text { Ischemia- reperfusion } \\
\text { injury in mice }\end{array}$ & $\begin{array}{l}\text { Protect against } \\
\text { ischemic acute renal } \\
\text { failure partially } \\
\text { through paracrine } \\
\text { factor VEGF }\end{array}$ & $\begin{array}{l}\text { Enhanced renal function and } \\
\text { reduced tubular cell apoptosis }\end{array}$ & (Jiang, et al., 2015) \\
\hline c-Kit & Neonatal & $\begin{array}{l}\text { Supra- } \\
\text { renal aorta }\end{array}$ & $\begin{array}{l}\text { PAN-induced acute } \\
\text { proteinuria in rats }\end{array}$ & $\begin{array}{l}\text { Recovery of podocyte } \\
\text { cytoskeleton and } \\
\text { activation of } \\
\text { phosphorylated } \\
\text { mTOR Ser } 2481 \\
\text { in renal tissue }\end{array}$ & $\begin{array}{l}\text { Tubular epithelial cell recovery } \\
\text { in a paracrine manner }\end{array}$ & $\begin{array}{r}\text { (Gomes et al., 2018; } \\
\text { Rangeet al., 2018) }\end{array}$ \\
\hline
\end{tabular}

AKI, acute kidney injury; BUN blood urea nitrogen; CKD, chronic kidney disease; IV, intravenous; mTOR, mechanistic target of rapamycin; PAN, puromycin amino nucleoside; SCID, severe combined immunodeficiency; VEGF, vascular endothelial growth factor. 


\section{CONFLICTS OF INTEREST}

No potential conflict of interest relevant to this article was reported.

\section{ACKNOWLEDGEMENTS}

This work was supported by Basic Science Research Program through the National Research Foundation of Korea (NRF) funded by the Ministry of Education (2018R1D1A1A02085481).

\section{ORCID}

Jeong Hyun Jo: https://orcid.org/0000-0002-2136-1492

Ki Hoon Kim: https://orcid.org/0000-0002-4913-6617

Tae Min Kim: https://orcid.org/0000-0003-0015-2701

\section{REFERENCES}

Aggarwal S, Grange C, Iampietro C, Camussi G, Bussolati, B. 2016. Human CD133(+) Renal Progenitor Cells Induce Erythropoietin Production and Limit Fibrosis After Acute Tubular Injury. Sci Rep 6: 37270.

Angelotti ML, Ronconi E, Ballerini L, Peired A, Mazzinghi B, Sagrinati C, Parente E, Gacci M, Carini M, Rotondi M, Fogo AB, Lazzeri E, Lasagni L, Romagnani P. 2012. Characterization of renal progenitors committed toward tubular lineage and their regenerative potential in renal tubular injury. Stem Cells 30(8): 1714-1725.

Biancone L and Camussi G. 2014. Potential use of stem or progenitor cells for kidney regeneration. Nat Rev nephrol 10(2): 67-68.

Bruno S, Bussolati B, Grange C, Collino F, di Cantogno LV, Herrera MB, Biancone L, Tetta C, Segoloni G, Camussi G. 2009. Isolation and characterization of resident mesenchymal stem cells in human glomeruli. Stem Cells Dev 18(6): 867880 .

Bruno S and Camussi G. 2012. Isolation and characterization of resident mesenchymal stem cells in human glomeruli. Methods Mol Biol 879: 367-380.

Bussolati B, Bruno S, Grange C, Buttiglieri S, Deregibus MC, Cantino D, Camussi G. 2005. Isolation of renal progenitor cells from adult human kidney. Am J Pathol 166(2): 545-555.

Gomes SA, Hare JM, Rangel EB. 2018. Kidney-Derived c-Kit(+) Cells Possess Regenerative Potential. Stem Cells Transl Med 7(4): 317-324.

Hansson J, Hultenby K, Cramnert C, Pontén F, Jansson H, Lindgren D, Axelson H, Johansson ME. 2014. Evidence for a morphologically distinct and functionally robust cell type in the proximal tubules of human kidney. Hum Pathol 45(2): 382393.
Harari-Steinberg O, Metsuyanim S, Omer D, Gnatek Y, Gershon R, Pri-Chen S, Ozdemir DD, Lerenthal Y, Noiman T, Ben-Hur H, Vaknin Z, Schneider DF, Aronow BJ, Goldstein RS, Hohenstein P, Dekel B. 2013. Identification of human nephron progenitors capable of generation of kidney structures and functional repair of chronic renal disease. EMBO Mol Med 5(10): 1556-1568.

Hauser PV, De Fazio R, Bruno S, Sdei S, Grange C, Bussolati B, Benedetto C, Camussi G. 2010. Stem cells derived from human amniotic fluid contribute to acute kidney injury recovery. Am J Pathol 177(4): 2011-2021.

Jha V, Garcia-Garcia G, Iseki K, Li Z, Naicker S, Plattner B, Saran R, Wang AY, Yang CW. 2013. Chronic kidney disease: global dimension and perspectives. Lancet 382(9888): 260- 272.

Jiang MH, Li G, Liu J, Liu L, Wu B, Huang W, He W, Deng C, Wang D, Li C, Lahn BT, Shi C, Xiang AP. 2015. Nestin(+) kidney resident mesenchymal stem cells for the treatment of acute kidney ischemia injury. Biomaterials 50: 56-66.

Kuppe C, Kramann R. 2016. Role of mesenchymal stem cells in kidney injury and fibrosis. Curr Opin Nephrol Hypertens 25(4): 372-377.

Lazzeri E, Crescioli C, Ronconi E, Mazzinghi B, Sagrinati C, Netti GS, Angelotti ML, Parente E, Ballerini L, Cosmi L, Maggi L, Gesualdo L, Rotondi M, Annunziato F, Maggi E, Lasagni L, Serio M, Romagnani S, Vannelli GB, Romagnani P. 2007. Regenerative potential of embryonic renal multipotent progenitors in acute renal failure. J Am Soc Nephrol 18(12): 3128-3138.

Miliaras D, Karasavvidou F, Papanikolaou A, Sioutopoulou D. 2004. KIT expression in fetal, normal adult, and neoplastic renal tissues. Journal of Clinical Pathology 57(5): 463-466.

Qi S and Wu D. 2013. Bone marrow-derived mesenchymal stem cells protect against cisplatin-induced acute kidney injury in rats by inhibiting cell apoptosis. Int J Mol Med 32(6): 12621272.

Rangel EB, Gomes SA, Kanashiro-Takeuchi R, Saltzman RG, Wei C, Ruiz P, Reiser J, Hare JM. 2018. Kidney-derived ckit(+) progenitor/stem cells contribute to podocyte recovery in a model of acute proteinuria. Sci Rep 8(1):14723.

Rinkevich Y, Montoro DT, Contreras-Trujillo H, HarariSteinberg O, Newman AM, Tsai JM, Lim X, Van-Amerongen R, Bowman A, Januszyk M, Pleniceanu O, Nusse R, Longaker MT, Weissman IL, Dekel B. 2014. In vivo clonal analysis reveals lineage-restricted progenitor characteristics in mammalian kidney development, maintenance, and regeneration. Cell Rep 7(4): 1270-1283.

Romagnani P, Lasagni L, Remuzzi G. 2013. Renal progenitors: an evolutionary conserved strategy for kidney regeneration. Nat Rev Nephrol 9(3): 137-146.

Ronconi E, Sagrinati C, Angelotti ML, Lazzeri E, Mazzinghi B, Ballerini L, Parente E, Becherucci F, Gacci M, Carini M, Maggi E, Serio M, Vannelli GB, Lasagni L, Romagnani S, Romagnani P. 2009. Regeneration of glomerular podocytes by human renal progenitors. J Am Soc Nephrol 20(2): 322-332. 
Sagrinati C, Netti GS, Mazzinghi B, Lazzeri E, Liotta F, Frosali F, Ronconi E, Meini C, Gacci M, Squecco R, Carini M, Gesualdo L, Francini F, Maggi E, Annunziato F, Lasagni L, Serio M, Romagnani S, Romagnani P. 2006. Isolation and characterization of multipotent progenitor cells from the Bowman's capsule of adult human kidneys. J Am Soc Nephrol 17(9): 2443-2456.

Santeramo I, Herrera Perez Z, Illera A, Taylor A, Kenny S, Murray $\mathrm{P}$, Wilm B, Gretz N. 2017. Human Kidney-Derived Cells Ameliorate Acute Kidney Injury Without Engrafting into Renal Tissue. Stem Cells Transl Med 6(5): 1373-1384.

Sedrakyan S, Da Sacco S, Milanesi A, Shiri L, Petrosyan A, Varimezova R, Warburton D, Lemley KV, De Filippo RE, Perin L. 2012. Injection of amniotic fluid stem cells delays progres- sion of renal fibrosis. J Am Soc Nephrol 23(4): 661-673.

Togel FE, Westenfelder C. 2012. Kidney protection and regeneration following acute injury: progress through stem cell therapy. Am J Kidney Dis 60(6): 1012-1022.

Wang H, Gomez JA, Klein S, Zhang Z, Seidler B, Yang Y, Schmeckpeper J, Zhang L, Muramoto GG, Chute J, Pratt RE, Saur D, Mirotsou M, Dzau VJ. 2013. Adult renal mesenchymal stem cell-like cells contribute to juxtaglomerular cell recruitment." J Am Soc Nephrol 24(8): 1263-1273.

Ward HH1, Romero E, Welford A, Pickett G, Bacallao R, Gattone VH 2nd, Ness SA, Wandinger-Ness A, Roitbak T. 2011. Adult human CD133/1(+) kidney cells isolated from papilla integrate into developing kidney tubules. Biochim Biophys Acta 1812(10): 1344-1357. 